\title{
Effects of caffeic acid phenethyl ester on palatal mucosal defects and tooth extraction sockets
}

\author{
This article was published in the following Dove Press journal: \\ Drug Design, Development and Therapy \\ 23 October 2014 \\ Number of times this article has been viewed
}

\author{
Ahmet Günay' \\ Osman Fatih Arpağ \\ Serhat Atilgan ${ }^{3}$ \\ Ferhan Yaman ${ }^{3}$ \\ Yusuf Atalay ${ }^{4}$ \\ İzet Acikan ${ }^{3}$
}

'Department of Periodontology, Faculty of Dentistry, Dicle University, Diyarbakır, Turkey; ${ }^{2}$ Department of Periodontology, Faculty of Dentistry, Mustafa Kemal University, Hatay, Turkey; ${ }^{3}$ Department of Maxillofacial Surgery, Faculty of Dentistry, Dicle University, Diyarbakır, Turkey; ${ }^{4}$ Department of Maxillofacial Surgery, Faculty of Dentistry, Kocatepe University, Afyon, Turkey
Correspondence: Ahmet Günay Department of Periodontology, Faculty of Dentistry, Dicle University, PK 21280 Diyarbakir, Turkey Tel +90412248 8I 01 Ext 3355

Email ahmetgunay@dicle.edu.tr
Aim: The purpose of this study was to evaluate the effects of caffeic acid phenethyl ester (CAPE) on palatal mucosal defects and tooth extraction sockets in an experimental model.

Materials and methods: Forty-two male Sprague-Dawley rats with a mean age of 7 weeks and weighing 280-490 g were used in this study. The rats were randomly divided into two groups: group A (the control group, $\mathrm{n}=21$ ) and group $\mathrm{B}$ (the experimental group, $\mathrm{n}=21$ ). Under anesthesia with ketamine ( $8 \mathrm{mg} / 100 \mathrm{~g}$, intraperitoneally), palatal mucosal defects were created and tooth extraction was performed in the rats in groups A and B. Group A received no treatment, whereas group B received CAPE. CAPE was injected daily $(10 \mu \mathrm{mol} / \mathrm{kg}$, intraperitoneally). The rats were killed on days 7,14 , and 30 after the procedures. Palatal mucosa healing and changes in bone tissue and fibrous tissue were evaluated histopathologically.

Result: Pairwise comparisons showed no statistically significant difference between days 7 and 14 in either group $(P>0.05)$. At day 30 , bone healing was significantly better in group B (CAPE) than in group A (control) $(P<0.05)$. Fibrinogen levels at day 30 were significantly higher in group A (control) than in group B (CAPE) $(P<0.05)$. Pairwise comparisons showed no statistically significant difference in palatal mucosa healing levels between days 7 and 14 in both groups $(P>0.05)$.

Conclusion: In conclusion, the findings of this study suggest that CAPE can significantly improve tooth socket healing.

Keywords: caffeic acid phenyl ester, palatal mucosa, tooth extraction socket, healing

\section{Introduction}

Wound healing is a highly ordered and well-coordinated process that involves inflammation, cell proliferation, matrix deposition, and tissue remodeling. ${ }^{1}$ Sufficient oral soft tissues and favorable architecture of the alveolar bone are essential to obtaining ideal functional and aesthetic prosthetic reconstruction in all periods of life. Knowledge of the healing process at extraction sites and the mucosa, including contour changes caused by bone resorption and remodeling, is essential. Loss of alveolar bone may occur before tooth extraction because of periodontal disease, periapical pathology, or trauma to teeth and bone. Damage of the hard and soft tissues during tooth extraction procedures may also result in bone loss. ${ }^{2}$

Nutrition is fundamental to maintaining health. Accelerated tooth socket healing and oral mucosal healing are important for masticatory functions.

Caffeic acid phenethyl ester (CAPE) is a biologically active ingredient extracted from propolis that is used for the isolation and disinfection of hives. ${ }^{3,4} \mathrm{CAPE}$ is known to have antioxidative, anti-inflammatory, and anticancer activities. ${ }^{5} \mathrm{It}$ is also a specific inhibitor of the nuclear transcription factor nuclear factor (NF)- $\mathrm{BB} .{ }^{6} \mathrm{CAPE}$ has been shown to significantly suppress the lipoxygenase pathway of arachidonic acid metabolism during inflammation. ${ }^{7}$ It has also been shown to inhibit HIV-1 integrase ${ }^{8}$ and the 
proliferation of transformed cells ${ }^{9}$ and induces apoptosis in transformed fibroblasts. ${ }^{10}$

CAPE, via suppression of RANKL-induced NF- $\kappa$ B and NFAT activation, has dual effects on osteoclasts; that is, inhibiting osteoclastogenesis and inducing apoptosis. Given that many pathological bone diseases are associated with increased osteoclast formation and activation, our studies imply that this remarkable natural compound might be useful for the prevention or treatment of osteolytic bone diseases. ${ }^{11}$

The above-described studies show that CAPE is effective in terms of suppressing the inflammatory compounds that cause fibrotic healing and suggest that CAPE may have beneficial effects on soft tissue and tooth extraction socket healing. This study aimed to assess the effects of CAPE on oral soft and hard tissue wounds: tooth extraction sockets and palatal mucosal defects.

\section{Materials and methods}

Forty-two male Sprague-Dawley rats with a mean age of 7 weeks and a weight of 280-490 g were used in this study, which was conducted at the Health Institution Research Centre, Dicle University, Diyarbakir, Turkey. The rats were housed individually in plastic cages in a controlled environment $\left(21^{\circ} \mathrm{C}\right.$; 12-hour light/12-hour dark cycle) and had free access to drinking water and a diet of standard laboratory rat food pellets. They were randomly divided into two groups and anesthetized with ketamine $(8 \mathrm{mg} / 100 \mathrm{~g}$, intraperitoneally). In group $A$ (the control group, $n=21$ ) and group $B$ (the experimental group, $n=21$ ), palatal mucosal defects were created and tooth extraction was performed. Group A received no treatment, whereas group B received CAPE. CAPE was injected daily (10 $\mu \mathrm{mol} / \mathrm{kg}$, intraperitoneally).

\section{Palatal mucosal defect procedure}

The surgical procedures were performed with the animals under ketamine $\mathrm{HCl}(35 \mathrm{mg} / \mathrm{kg})$ and xylazine $(3 \mathrm{mg} / \mathrm{kg})$ anesthesia. Full-thickness excisional wounds were made on the left side of the hard palatal mucosa, using a $3 \mathrm{~mm}$ biopsy punch. All the procedures were performed by the same researcher under aseptic conditions.

\section{Tooth extraction procedure}

The left first mandibular molar (M1) was extracted from each rat with a dental explorer (\#23). The tip of this instrument was first placed at the distobuccal gingival margin between the first and second molars. The dental explorer was repeatedly rotated in a dorsal and mesial direction to loosen the first molar. The tip was then removed from its original position, placed at the bifurcation between the mesial and distal roots of the first molar, and repeatedly rotated dorsally until extraction was achieved.

\section{Histological evaluation}

After surgery, seven rats per group were killed on days 7, 14 , and 30 , using high-dose ketamine. Bone regeneration, fibrotic healing, and osteoblast activity were evaluated by histopathology. Histological samples were fixed in $10 \%$ formalin for 72 hours. After dehydration in a graded alcohol series, they were embedded in paraffin. Then, transverse sections 4-5 $\mu \mathrm{m}$ in size were prepared for each tooth socket defect. All slices were stained with hematoxylin and eosin. Histological examination of the slides was carried out using a light microscope. All parameters were evaluated using a blinded histological scoring technique by an experienced histologist. For each defect, the parameters were scored as 0 (none), 1 (poor), 2 (average), and 3 (good).

All animal procedures were approved by the Animal Research Committee of Dicle University and were performed in compliance with the Medical Research Centre university guidelines for the care and handling of experimental animals.

\section{Statistical analysis}

Statistical calculations were carried out with SPSS 15 for Windows (SPSS Inc., Chicago, IL, USA). For all evaluated parameters, normality was tested by the Shapiro-Wilk test. The statistical analyses were performed after the distribution of values was known. Mann-Whitney $U$-tests were used for between-group comparisons for each point. The level of statistical significance was set at $P<0.05$.

\section{Results}

There was no statistically significant difference in fibrinogen levels and bone healing between days 7 and 14 in the two groups $(P>0.05)$ (Figures 1-4). Bone healing at day 30 was significantly better in group B (CAPE) than in group A (control) $(P<0.05$; Figures 5 and 6$)$. Fibrinogen levels at day 30 were significantly higher in group A (control) than in group B (CAPE) $(P<0.05$; Table 1 and Figure 7$)$.

There was no statistically significant difference in palatal mucosa healing between days 7 and 14 in both groups $(P>0.05)$ (Figures 8-12 and Table 2).

\section{Discussion}

The present study demonstrated that treatment with CAPE influenced tooth socket healing and soft tissue oral structure in an experimental model, as determined by histopathological methods. ${ }^{12,13}$ Histopathological assessment revealed significantly improved tooth socket healing with CAPE treatment compared with in untreated controls. Magro Filho and de Carvalho assessed 


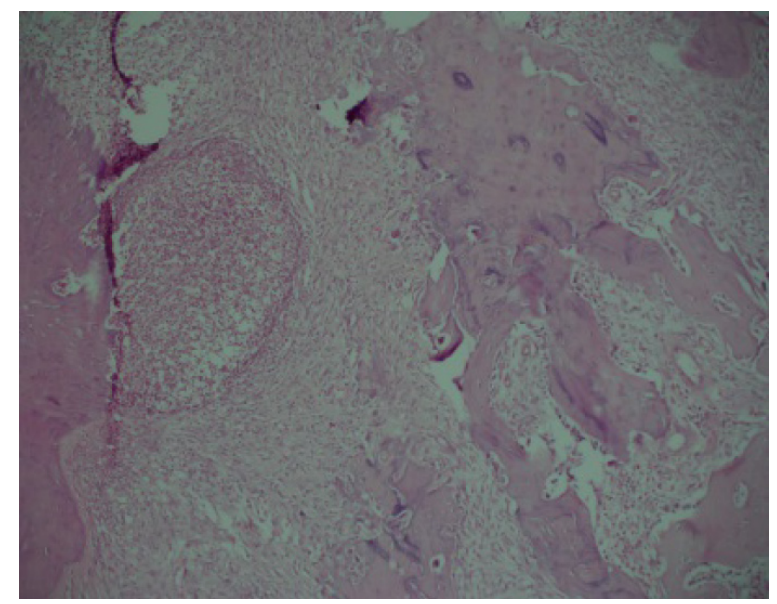

Figure I Control group at day 7.

Note: Newly formed chondroid and immature bone tissue in inflammatory granulation tissue (hematoxylin and eosin, 100x).

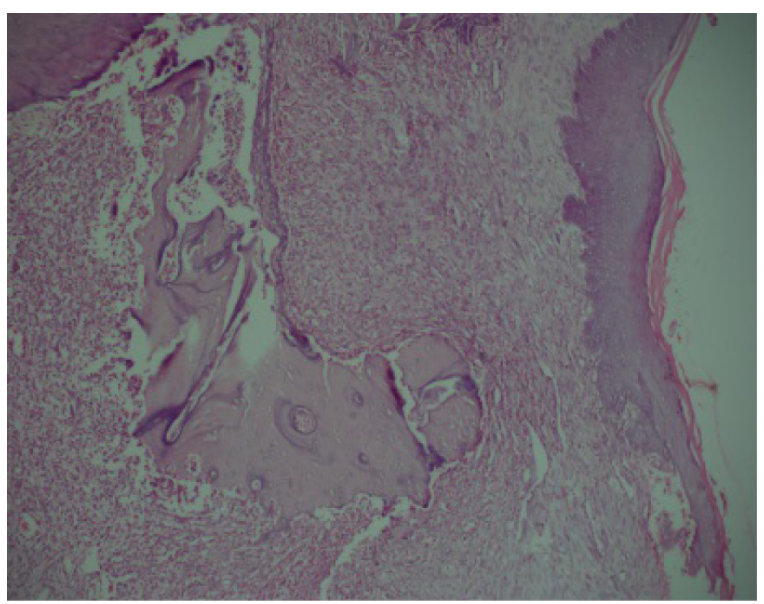

Figure 2 Caffeic acid phenethyl ester group at day 7 .

Note: Newly formed chondroid and immature bone tissue in inflammatory granulation tissue (hematoxylin and eosin, 100x).

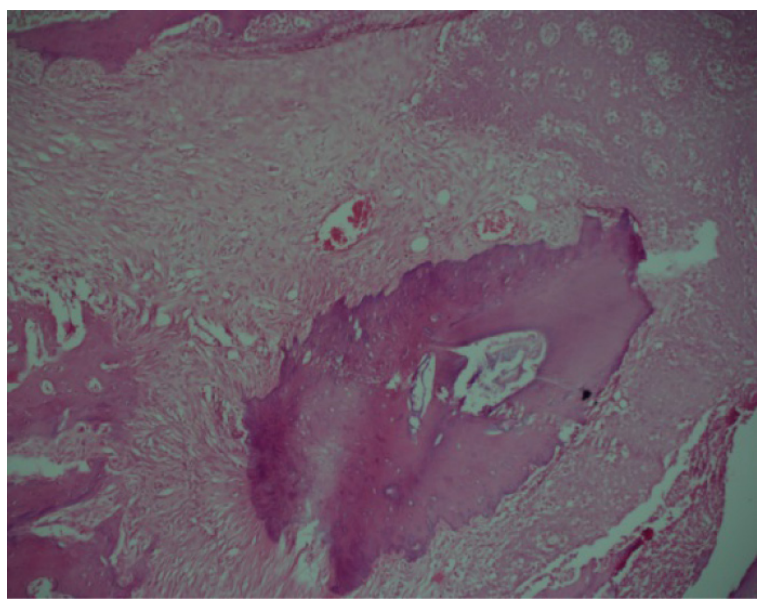

Figure 3 Control group at day 14.

Note: Newly formed trabecular bone zone in inflammatory granulation tissue (hematoxylin and eosin, 100x).

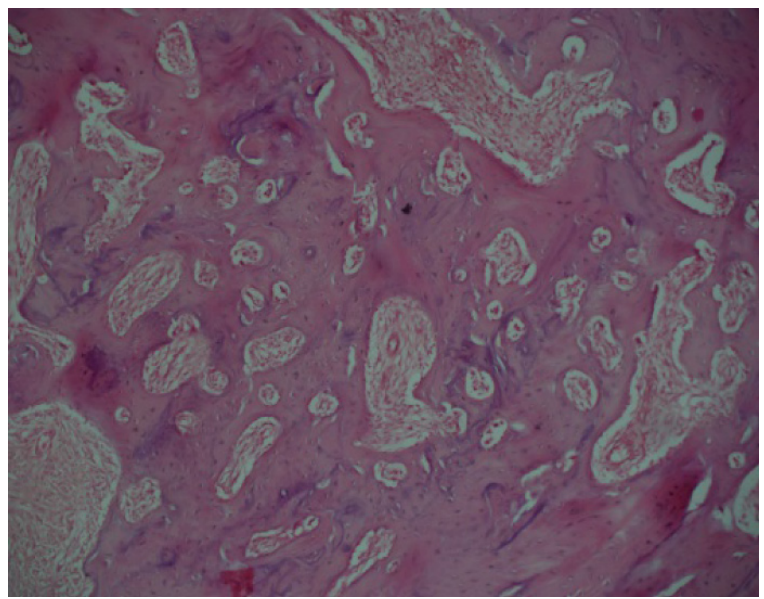

Figure 4 Caffeic acid phenethyl ester group at day 14 .

Note: Trabecular bone tissue containing a small amount of connective tissue (hematoxylin and eosin, 100x).

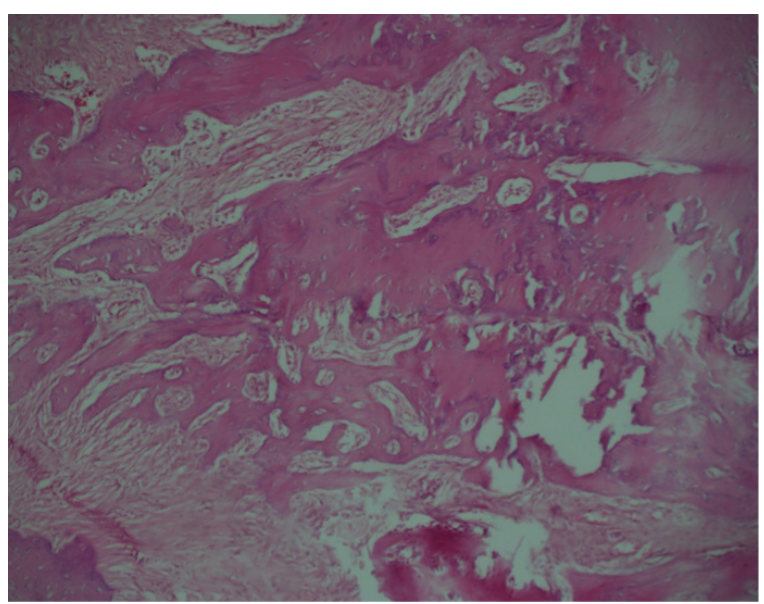

Figure 5 Control group at day 30.

Note: Trabecular bone tissue containing a small amount of connective tissue (hematoxylin and eosin, 100x).

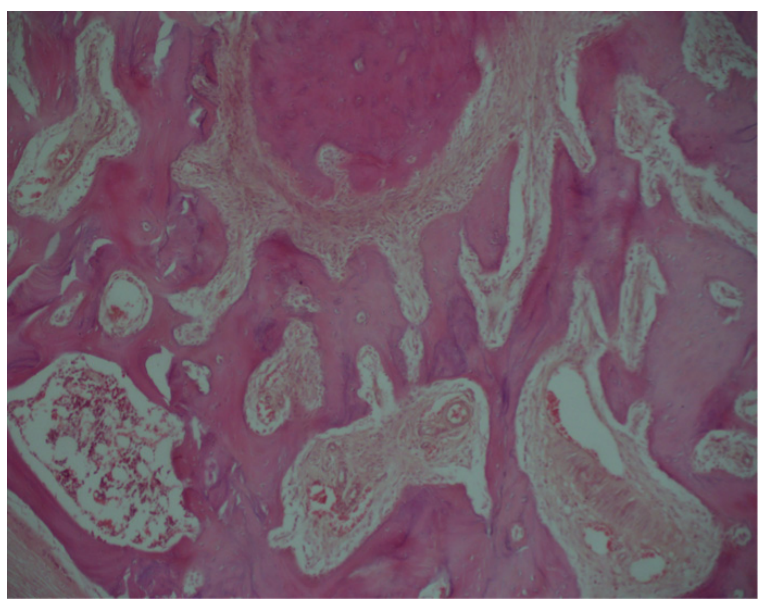

Figure 6 Caffeic acid phenethyl ester group at day 30 .

Note: Trabecular bone tissue containing a small amount of connective tissue (hematoxylin and eosin, 100x). 
Table I Statistical analysis of tooth sockets at days 7, 14, and 30

\begin{tabular}{|c|c|c|c|}
\hline $\begin{array}{l}\text { Day and } \\
\text { variable }\end{array}$ & $\begin{array}{l}\text { Caffeic acid } \\
\text { phenethyl ester } \\
(n=21)\end{array}$ & $\begin{array}{l}\text { Control } \\
(n=2 I)\end{array}$ & $\begin{array}{l}\text { P-value, } \\
\text { Mann-Whitney U }\end{array}$ \\
\hline \multicolumn{4}{|l|}{ Day 7} \\
\hline Bone & $0.428 \pm 0.121$ & $0.321 \pm 0.188$ & $0.244^{\mathrm{NS}}$ \\
\hline Fibrin & $1.00 \pm 0.204$ & $1.107 \pm 0.133$ & $0.293^{\mathrm{NS}}$ \\
\hline \multicolumn{4}{|l|}{ Day 14} \\
\hline Bone & $0.642 \pm 0.133$ & $0.500 \pm 0.144$ & $0.08 I^{\text {NS }}$ \\
\hline Fibrin & $0.857 \pm 0.133$ & $1.035 \pm 0.172$ & $0.058^{\mathrm{NS}}$ \\
\hline \multicolumn{4}{|l|}{ Day 30} \\
\hline Bone & $2.035 \pm 0.267$ & I. $428 \pm 0.345$ & $0.009 *$ \\
\hline Fibrin & $0.607 \pm 0.133$ & $0.928 \pm 0.278$ & $0.027^{*}$ \\
\hline
\end{tabular}

Notes: NS, no statistically significant between-group difference $(P>0.05$; MannWhitney U-test). *Statistically significant between-group difference $(P<0.05$ MannWhitney $U$-test). Data are shown as mean \pm standard deviation.

the effects of topical application of CAPE to dental sockets and skin wounds histologically. They reported that topical application of CAPE accelerated epithelial repair after tooth extraction but had no effect on socket healing. ${ }^{14}$ Few experimental studies on palatal mucosa healing have been reported. ${ }^{15-17}$

Hard palate wounds can occur directly as a result of various etiological factors, including tooth extraction, traumatic injuries, and the resection of neoplasms, or indirectly as a result of surgical procedures. ${ }^{18,19}$ Notably, during periodontal plastic surgery and gingival recession treatment procedures, the palatal masticatory mucosa is often injured and is widely used as a donor connective tissue source..$^{20}$

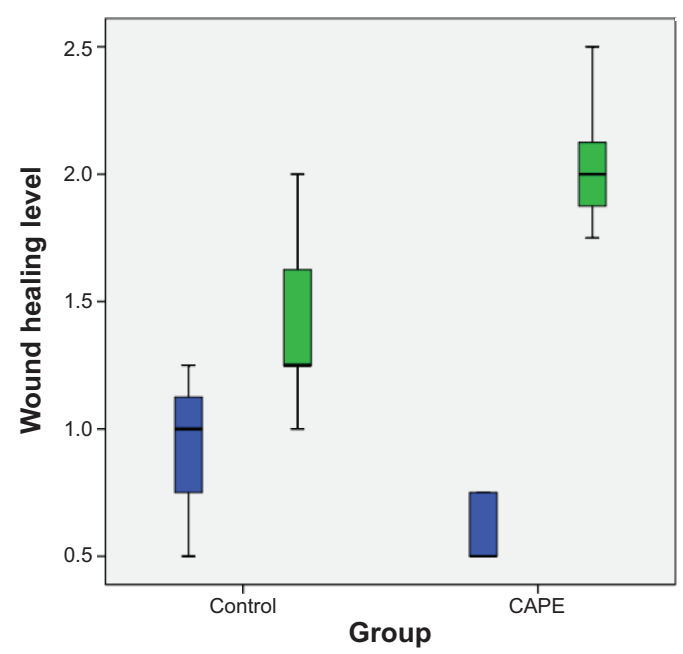

口FIBR_30 ᄃBONE_30

Figure 7 Histopathological values for tooth sockets at day 30

Notes: Box-whisker plot showing the correlation between fibrinogen (FIBR) and bone healing in the tooth extraction area. Rats were randomly assigned to two groups: control (palatal mucosal defect with no treatment, $n=2 I$ ) and caffeic acid phenethyl ester (palatal mucosal defect treated with caffeic acid phenethyl ester [caffeic acid phenethyl ester, $10 \mu \mathrm{mol} / \mathrm{kg}$, daily intraperitoneal injection], $\mathrm{n}=2 \mathrm{I}$ ). The heavy black horizontal lines show the mean values; the ends of the boxes are the 25 th and 75th percentiles; and the error bars represent maximum and minimum values. Abbreviation: CAPE, caffeic acid phenethyl ester.

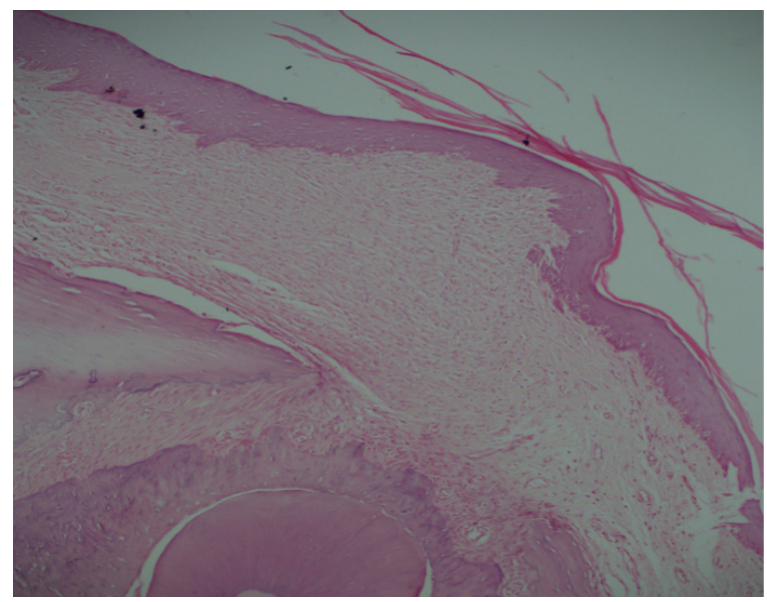

Figure 8 Control group at day 7 .

Note: Surface covered with a thick layer of epithelium in the subepithelial granulation tissue area (hematoxylin and eosin, 100x).

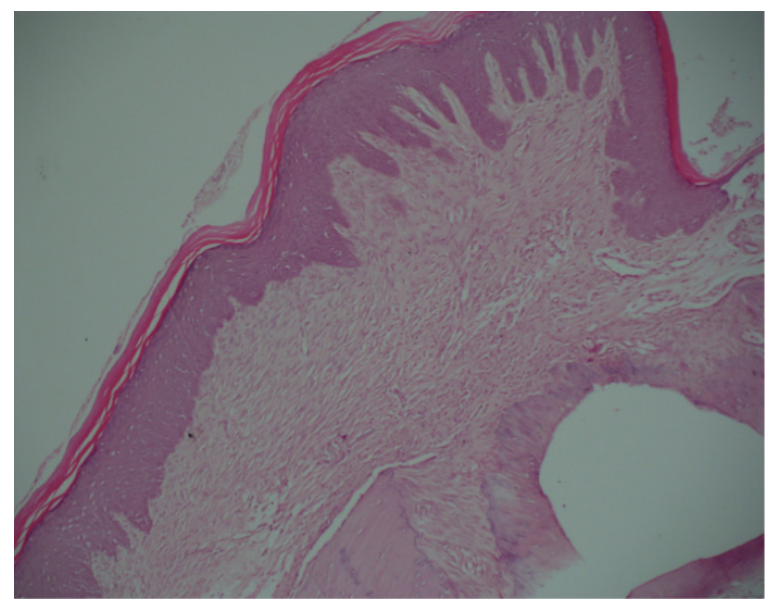

Figure 9 Caffeic acid phenethyl ester group at day 7 .

Note: Surface covered with a thick layer of epithelium in the subepithelial granulation tissue area (hematoxylin and eosin, I00x).

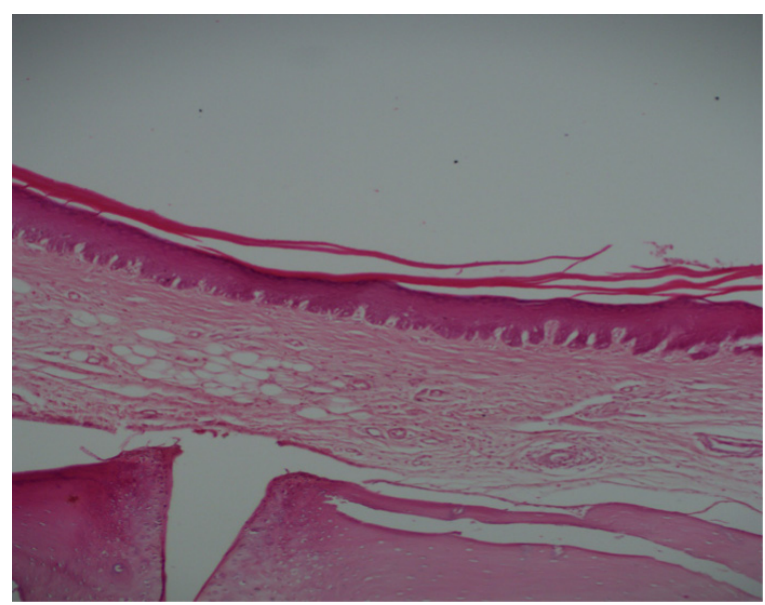

Figure 10 Control group at day 14

Note: Modest increase in fibrous tissue under the near-normal epithelial layer (hematoxylin and eosin, 100x). 


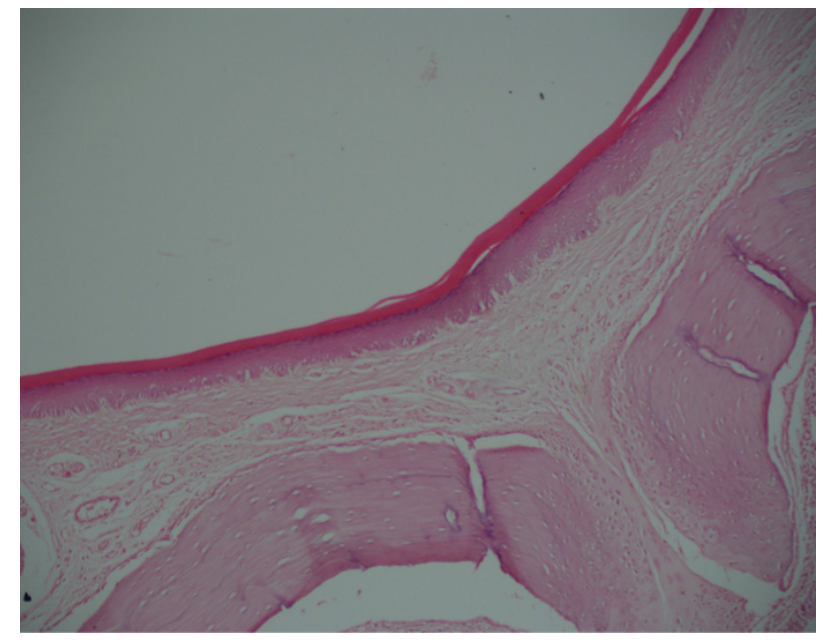

Figure I I Caffeic acid phenethyl ester group at day 14.

Note: Increased fibrous tissue under the near-normal epithelial layer (hematoxylin and eosin, 100x).

No histological evaluation of palatal mucosa was performed at day 30 because of the rapid wound closure in the palatal mucosa. In general, palatal mucosal wounds heal rapidly. At 14 days after wounding, palatal mucosal wounds are clinically closed. ${ }^{21}$ Therefore, we did not evaluate palatal mucosa healing at day 30 .

Santos and colleagues evaluated the clinical efficacy of a new Brazilian propolis gel formulation in patients diagnosed with denture stomatitis. They verified the complete clinical remission of palatal edema and erythema and suggested that

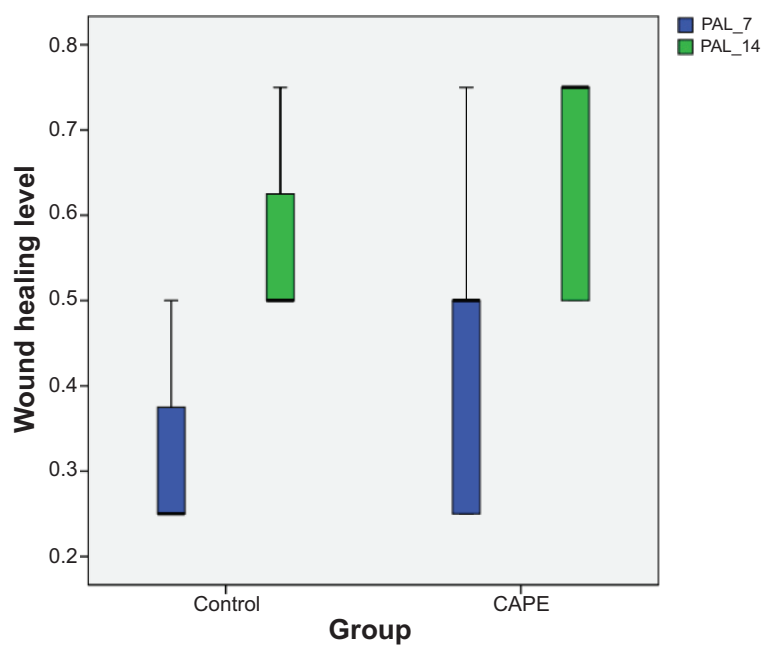

Figure 12 Wound healing values for palatal mucosa at days 7 and 14

Notes: Box-whisker plot showing the wound healing values for palatal mucosa at days 7 and I4 (PAL_7, PAL_I4). Rats were randomly assigned to two groups: control (tooth extraction defect with no treatment, $n=2 \mathrm{I}$ ) and caffeic acid phenethyl ester (tooth extraction defect treated with caffeic acid phenethyl ester [caffeic acid phenethyl ester, $10 \mu \mathrm{mol} / \mathrm{kg}$, daily intraperitoneal injection], $\mathrm{n}=2 \mathrm{I}$ ). The heavy black horizontal lines show the mean values; the ends of the boxes are the 25th and 75th percentiles; and the error bars represent maximum and minimum values.

Abbreviation: CAPE, caffeic acid phenethyl ester.
Table 2 Statistical analysis of palatal mucosa at days 7 and 14

\begin{tabular}{llll}
\hline Day & $\begin{array}{l}\text { Caffeic acid } \\
\text { phenethyl ester }\end{array}$ & Control & P-value \\
\hline 7 & $0.426 \pm 0.188$ & $0.321 \pm 0.121$ & $0.244^{\mathrm{NS}}$ \\
14 & $0.642 \pm 0.133$ & $0.574 \pm 0.121$ & $0.298^{\mathrm{NS}}$ \\
\hline
\end{tabular}

Notes: NS, no statistically significant between-group difference $(P>0.05$; MannWhitney $U$-test). Data are shown as mean \pm standard deviation.

this gel was effective and could be an alternative topical treatment of denture stomatitis. ${ }^{22}$

One study reported that local CAPE administration accelerates epithelial healing. ${ }^{14}$ However, systemic administration of CAPE had no positive effect on palatal mucosa healing in our study. Although there was no significant difference in palatal mucosa healing, healing was better in the CAPE group than in the control group (Table 2).

Toker and colleagues analyzed the morphometric and histopathological changes associated with experimental periodontitis in rats in response to the systemic administration of CAPE. CAPE significantly reduced periodontitisrelated bone loss. The findings of this study provided morphological and histological evidence that CAPE, when administered systemically, prevented alveolar bone loss in the rat model. ${ }^{23}$

Guney and colleagues reported that CAPE has beneficial effects on fracture healing, as assessed by several methods, including bone mineral density measurement and radiographic and histopathological evaluation. These findings were supported by changes in the levels of endogenous antioxidant molecules compared with controls. ${ }^{24}$

Erdem and coworkers stated that use of CAPE can enhance the maturation of newly regenerated bone. ${ }^{25}$

In our study, bone healing in the tooth socket at day 30 was better in rats treated with CAPE than in control rats (Table 1). Therefore, CAPE increased osteoblastic activity in the tooth extraction socket.

Magro-Filho and de Carvalho showed that local application of CAPE facilitates healing of wounds after surgery in the oral cavity, reduces inflammation, and has an analgesic effect. ${ }^{26}$ In addition, Lopes-Rocha and colleagues noted a beneficial effect of bee glue on the healing of surgical wounds in the oral cavity. CAPE decreased inflammation and accelerated granulation tissue formation and epithelialization. ${ }^{27}$

Uçan and colleagues reported that CAPE significantly improved bone defect healing in an experimental study and that CAPE has beneficial effects on bone healing. ${ }^{28}$ Our findings indicated that treatment with CAPE had beneficial effects on bone healing, as assessed by histopathological evaluation. 


\section{Conclusion}

Systemic administration of CAPE has a positive effect on tooth socket healing but does not improve soft tissue healing. We suggest that studies including a greater number of animals and local administration of CAPE be carried out before clinical trials are designed.

\section{Disclosure}

The authors report no conflicts of interest in this work.

\section{References}

1. Goldsmith LA, Clark RAF. In: Goldsmith LA, ed. Physiology, Biochemistry, and Molecular Biology of the Skin. NY: Oxford University Press; 1991:576-601.

2. Schropp L, Wenzel A, Kostopoulos L, Karring T. Bone healing and soft tissue contour changes following single-tooth extraction: a clinical and radiographic 12-month prospective study. Int J Periodontics Restorative Dent. 2003;23(4):313-323.

3. Dobrowolski JW, Vohora SB, Sharma K, Shah SA, Naqvi SA, Dandiya PC. Antibacterial, antifungal, antiamoebic, antiinflammatory and antipyretic studies on propolis bee products. $J$ Ethnopharmacol. 1991;35(1):77-82.

4. Su ZZ, Lin J, Grunberger D, Fisher PB. Growth suppression and toxicity induced by caffeic acid phenethyl ester (CAPE) in type 5 adenovirustransformed rat embryo cells correlate directly with transformation progression. Cancer Res. 1994;54(7):1865-1870.

5. Michaluart P, Masferrer JL, Carothers AM, et al. Inhibitory effects of caffeic acid phenethyl ester on the activity and expression of cyclooxygenase- 2 in human oral epithelial cells and in a rat model of inflammation. Cancer Res. 1999;59(10):2347-2352.

6. Natarajan K, Singh S, Burke TR Jr, Grunberger D, Aggarwal BB. Caffeic acid phenethyl ester is a potent and specific inhibitor of activation of nuclear transcription factor NF-kappa B. Proc Natl Acad Sci U S A. 1996;93(17):9090-9095.

7. Paulino N, Dantas AP, Bankova V, et al. Bulgarian propolis induces analgesic and anti-inflammatory effects in mice and inhibits in vitro contraction of airway smooth muscle. J Pharmacol Sci. 2003;93(3): 307-313.

8. Fesen MR, Pommier Y, Leteurtre F, Hiroguchi S, Yung J, Kohn KW. Inhibition of HIV-1 integrase by flavones, caffeic acid phenethyl ester (CAPE) and related compounds. Biochem Pharmacol. 1994; 48(3):595-608.

9. Lin J, Su Z, Grunberger D, Zimmer S, Fisher P. Expression of the transformed phenotype induced by diverse acting viral oncogenes mediates sensitivity to growth suppression induced by caffeic Acid phenethyl ester (cape). Int J Oncol. 1994;5(1):5-15.

10. Chiao C, Carothers AM, Grunberger D, Solomon G, Preston GA, Barrett JC. Apoptosis and altered redox state induced by caffeic acid phenethyl ester (CAPE) in transformed rat fibroblast cells. Cancer Res. 1995;55(16):3576-3583.

11. Ang ES, Pavlos NJ, Chai LY, et al. Caffeic acid phenethyl ester, an active component of honeybee propolis attenuates osteoclastogenesis and bone resorption via the suppression of RANKL-induced NF-kappaB and NFAT activity. $J$ Cell Physiol. 2009;221(3):642-649.

Drug Design, Development and Therapy

\section{Publish your work in this journal}

Drug Design, Development and Therapy is an international, peerreviewed open-access journal that spans the spectrum of drug design and development through to clinical applications. Clinical outcomes, patient safety, and programs for the development and effective, safe, and sustained use of medicines are a feature of the journal, which
12. Findikcioglu K, Findikcioglu F, Yavuzer R, Elmas C, Atabay K. Effect of platelet-rich plasma and fibrin glue on healing of critical-size calvarial bone defects. J Craniofac Surg. 2009;20(1):34-40.

13. Findikcioglu F, Findikcioglu K, Yavuzer R, Lortlar N, Atabay K. Effect of preoperative subcutaneous platelet-rich plasma and fibrin glue application on skin flap survival. Aesthetic Plast Surg. 2012; 36(5):1246-1253.

14. Magro Filho O, de Carvalho AC. Application of propolis to dental sockets and skin wounds. J Nihon Univ Sch Dent. 1990;32(1):4-13.

15. Cornelissen AM, Von den Hoff JW, Maltha JC, Kuijpers-Jagtman AM. Effects of locally injected interferon-beta on palatal mucoperiosteal wound healing. J Oral Pathol Med. 2002;31(9):518-525.

16. Choi W, Kawanabe H, Sawa Y, Taniguchi K, Ishikawa H. Effects of bFGF on suppression of collagen type I accumulation and scar tissue formation during wound healing after mucoperiosteal denudation of rat palate. Acta Odontol Scand. 2008;66(1):31-37.

17. Firat ET, Dağ A, Günay A, et al. The effect of low-level laser therapy on the healing of hard palate mucosa and the oxidative stress status of rats. J Oral Pathol Med. 2014;43(2):103-110.

18. Luskin IR. Reconstruction of oral defects using mucogingival pedicle flaps. Clin Tech Small Anim Pract. 2000;15(4):251-259.

19. Ramakrishnan T, Kaur M, Aggarwal K. Root coverage using epithelial embossed connective tissue graft. Indian J Dent Res. 2011;22(5): 726-728.

20. Monnet-Corti V, Santini A, Glise JM, et al. Connective tissue graft for gingival recession treatment: assessment of the maximum graft dimensions at the palatal vault as a donor site. J Periodontol. 2006; 77(5):899-902.

21. Wong JW, Gallant-Behm C, Wiebe C, et al. Wound healing in oral mucosa results in reduced scar formation as compared with skin: evidence from the red Duroc pig model and humans. Wound Repair Regen. 2009;17(5):717-729.

22. Santos VR, Gomes RT, de Mesquita RA, et al. Efficacy of Brazilian propolis gel for the management of denture stomatitis: a pilot study. Phytother Res. 2008;22(11):1544-1547.

23. Toker H, Ozan F, Ozer H, Ozdemir H, Eren K, Yeler H. A morphometric and histopathologic evaluation of the effects of propolis on alveolar bone loss in experimental periodontitis in rats. $J$ Periodontol. 2008;79(6):1089-1094.

24. Guney A, Karaman I, Oner M, Yerer MB. Effects of propolis on fracture healing: an experimental study. Phytother Res. 2011;25(11): $1648-1652$.

25. Erdem M, Gulabi D, Sen C, Sahin SA, Bozdag E. Effects of caffeic acid phenethyl ester and melatonin on distraction osteogenesis: an experimental study. Springer Plus. 2014;3:8

26. Magro-Filho O, de Carvalho AC. Topical effect of propolis in the repair of sulcoplasties by the modified Kazanjian technique. Cytological and clinical evaluation. J Nihon Univ Sch Dent. 1994;36(2):102-111.

27. Lopes-Rocha R, Miranda JL, Lima NL, et al. Effect of topical propolis and dexamethasone on the healing of oral surgical wounds. Wound Healing Southern Africa. 2012;5(1):25-30.

28. Uçan MC, Koparal M, Ağaçayak S, et al. Influence of caffeic acid phenethyl ester on bone healing in a rat model. J Int Med Res. 2013; 41(5):1648-1654.

has also been accepted for indexing on PubMed Central. The manuscript management system is completely online and includes a very quick and fair peer-review system, which is all easy to use. Visit http://www.dovepress.com/testimonials.php to read real quotes from published authors. 